\title{
Measurements of Differential Capacity during Drop Growth at the Dropping Mercury Electrode adsorbed by Surface Active Substances
}

\author{
By \\ Yuzo Ayabe \\ National Chemical Laboratory for Industry (Tokyo Kogyo Shikensho), \\ 1-chome, Honmachi, Shibuya-ku, Tokyo
}

(Received Oct. 28, 1973)

\section{Synopsis}

The method for measurement of differential capacity using a small triangular wave voltage developed by Barker and Faircloth was applied to measurement of differential capacity-time curve during the drop life of mercury electrode adsorbed by surface active substances.

The change of relative coverage during the drop life for three kind of adsorbates were calculated from the differential capacity- $t^{1 / 2}$ curves. The adsorption process of the adsorbates became clear to be controlled by diffusion. For the case of tribenzylamine, it has been discussed that the adsorption process for early time of a drop life is controlled by diffusion.

Using the data of a dependence of relative coverage-time curves on temperature, the activation energy of diffusion of tetrabutylammonium ion, polyvinylalcohol and tribenzylamine has been evaluated on the basis of Koryta's equation.

\section{Introduction}

In the study of the influence of surface active substances on polarographic current, the differencial capacity of the electrode surface covered by adsorbent is a one of fundamental data ${ }^{1)}$. When the relationship between the current and time during a drop growth is discussed, it is necessary to measure the variation of the differential capacity and relative coverage during the life of dropping mercury electrode. For the measurement of differential capacity, Barker and Faircloth ${ }^{2}$ had reported a method using a small triangular wave voltage which is more convenient than a method using sunisoidal voltage $^{3)}$.

In the present work, we have studied the relative coverage which change with time during drop-growth using the small triangular voltage method, and the influence of temperature on the relative coverage. From the data obtained, we calculated the activation energy of diffusion of tetrabutylammonium ion (T.B.A.), polyvinylalcohol (P.V.A.) and tribenzylamine.

\section{Experimental}

Apparatus: Differential capacity-time curves were measured by means of an instrument the scheme of which is shown in Fig. 1. The dropping electrode was polarised by d.c. voltage supplied by potentiometer and triangular wave voltage (frequency $120 \mathrm{~Hz}$, amplitude $10 \mathrm{mV}$ p-p) was superimposed on d.c. voltage by use of a low frequency 
function generator (Hewlett Packard Model 202A). Resistance $\mathrm{R}(1-5 \mathrm{~K} \Omega)^{*}$ is connected in series to the $\mathrm{DME}$ in a circuit. The square wave voltage is slightly modified at the start of a half-cycle of the wave by time-constant RG ( $\mathrm{C}$ is the double layer capacity of the test $\mathrm{DME}$ ). The voltage through the resistance $\mathrm{R}$ is recored on the screen of the cathode-ray oscilloscope (Iwasaki Communication Apparatus Co., SS-5302B, plug-in unit $\mathrm{SP}-01 \mathrm{H}-\mathrm{B})$.

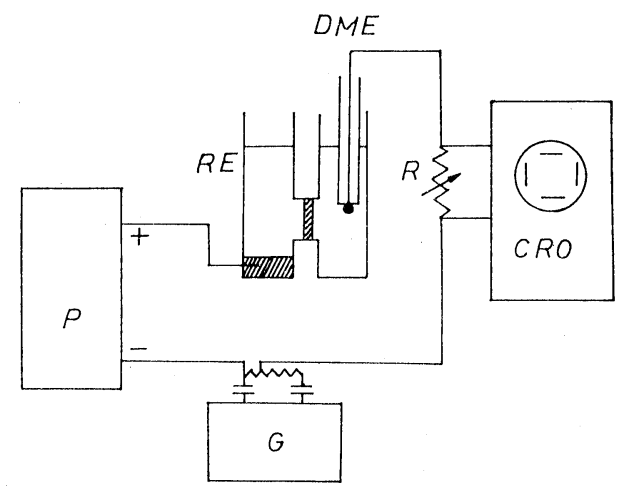

Fig. 1. Schematic diagram of circuit for measuring differential capacity during drop life.

$\mathrm{P}$; potentiometer, $\mathrm{G}$; low frequency function generator,

$\mathrm{RE}$; reference electrode, GRO; oscillograph

The vertical sensitivity is $0.2-0.5 \mathrm{mV} / \mathrm{cm}$ and horizontal sweep $1.0-0.5 \mathrm{sec} / \mathrm{cm}$. The temperature of mercury and sample solution was controlled at $25^{\circ} \mathrm{C}$ by "Coolnics" (Komatsu Electronics, CTR-1A, GTE-1A) except for experiments of the effect of temperature, i.e., water of $25^{\circ} \mathrm{C}$ was circulated continuously through the jackets of the cell and of the connecting tube between mercury pool and capillary. The saturated calomel electrode with the surface ares of about $11 \mathrm{~cm}^{2}$ was used as a counter electrode.

Chemicals: Water used was twice-distilled using a pyrex-glass and a quartz still, and mercury was distilled in a quartz still, after washing with diluted nitric acid and distilled water for three months. Guaranteed-grade reagents were used for all experiments. The degree of polymerization of polyvinylalcohol was ca. 1100. The electrolyte solutions used were $0.25 \mathrm{M}-\mathrm{KCl}$ for T.B.A., 0.1 or $0.2 \mathrm{~N}_{-} \mathrm{H}_{2} \mathrm{SO}_{4}$ for P.V.A., and $0.2 \mathrm{~N}$ $\mathrm{H}_{2} \mathrm{SO}_{4}$ or $0.2 \mathrm{~N}-\mathrm{HCl}$ for tribenzylamine.

Procedure: Nitrogen gas $(99.99 \%)$ was bubbled into the sample solution for one hour, and passed through the upper space of the cell during measurement. The resistance $\mathrm{R}$ was selected so that the flat part of the modified square wave becomes longer than a half of half-cycle. The horizontal sweep of CRO was synchronized to drop time, then the locus of a flat part of square wave showed two symmetrical curves with respect to the horizontal axis, as shown in Fig. 2. The vertical width (amplitude) of the symmetrical curves was directly proporional to the differential capacity of the electrical double layer of DME. It can be considered that three is no effect of capacity current due to d.c. potential on the vertical width of square wave except for nonsymmetrical part at very early time of the drop life. The value of the differential capacity can be calculated by comparing the amplitude of square wave for cell with the one when the cell is dis-

* a resistance due to electrolyte solution is negligibly small comparing to the reșistance $\mathrm{R}$, 
A

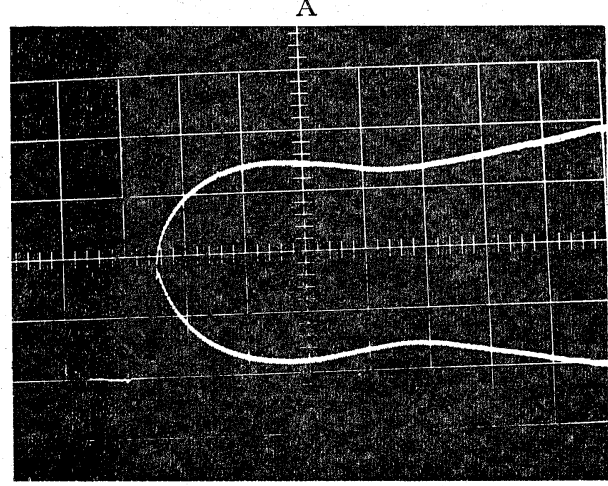

B

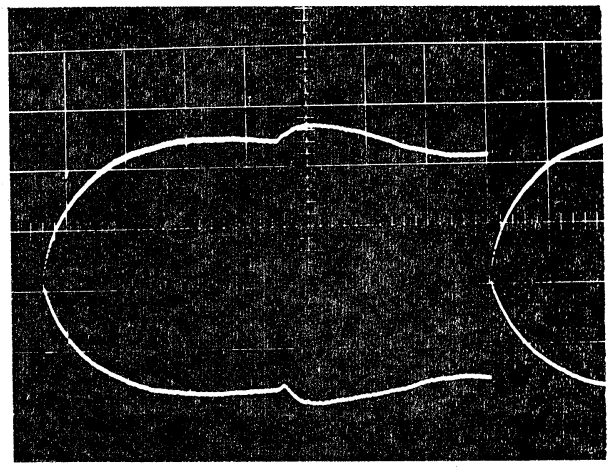

Fig. 2. Locus of square wave voltage during drop growth proportional to the change of capacity; horizontal sweep $1.0 \mathrm{sec} / \mathrm{cm}$, vertical sensitivity $0.5 \mathrm{mV} / \mathrm{cm}$

A ; $5 \times 19^{-5} M$-T.B.A. $+0.25 M-\mathrm{KCl}, E=-0.570 \mathrm{~V} ., 40^{\circ} \mathrm{C}$

B ; $5 \times 10^{-5} M$-tribenzylamine $+0.2 \mathrm{~N}-\mathrm{H}_{2} \mathrm{SO}_{4}, E=-0.422 \mathrm{~V} ., 25^{\circ} \mathrm{C}$

placed to the standard condenser.

\section{Results and Discussion}

When the current due to triangular wave voltage with p-p amplitude $\Delta E$ flows through the capacity $C$ and resistance $R$ in series, the square wave voltage $e$ is given as follows ${ }^{2}$ )

$$
e=R \cdot C \cdot \frac{\Delta E}{\Theta}\left\{1-\exp \left(-t^{\prime} / R C\right)\right\}
$$

where $\Theta$ is the half-peiod and $t^{\prime}$ the elapsed time of the half-period. Equation (1) shows that the amplitude of square wave voltage is directly proportional to the capacity.

If the surface active substance is strongly adsorbed on the DME, and the surface excess of the adsorbent is controlled by the diffusion, the relative coverage is expressed, according to Koryta ${ }^{4}$, by the following equation

$$
\theta=7.36 \times 10^{-4} \cdot c \cdot D^{1 / 2} \cdot I_{m}^{-1} \cdot t^{1 / 2}
$$

where $\theta$ is relative coverage $\left(\theta=I / \Gamma_{m}\right), c$ concentration of surface active substance, $D$ its diffusion coefficient, $I_{m}$ maximum surface concentration, $t$ the time of growth of one drop.

If the relative coverage changes negligibly with the change of the electrode potential, the relative coverage can be expressed as a function of the differential capacity by the following relation according to Frumkin ${ }^{5)}$.

$$
\theta=\left(C_{0}-C\right) /\left(C_{0}-C^{\prime}\right)
$$

where $C_{0}$ is the differential capacity at a given potential in the absence of surface active substance $(\theta=0), C^{\prime}$ is the differential capacity for $\theta=1$ and $C$ is the differential capacity at a given value of $\theta$.

From eqns. (2) and (3) it can be deduced that the differential capacity $C$ of DME in the presence of the surface active substance is proportional to $t^{1 / 2}$ between $\theta=0$ and $\theta=1$ at a given potential and a composition of electrolyte.

The dependence of the differential capacity $C$ in the presence of T.B.A., P.V.A., and tribenzylamine on $t^{1 / 2}$ are shown in Fig. 3, Fig. 4, Fig. 5, and Fig. 6. In Fig. 3 (T. B.A.) and Fig. 4 (P.V.A.), the plots are good straight lines. In the case of tribenzylamine, 


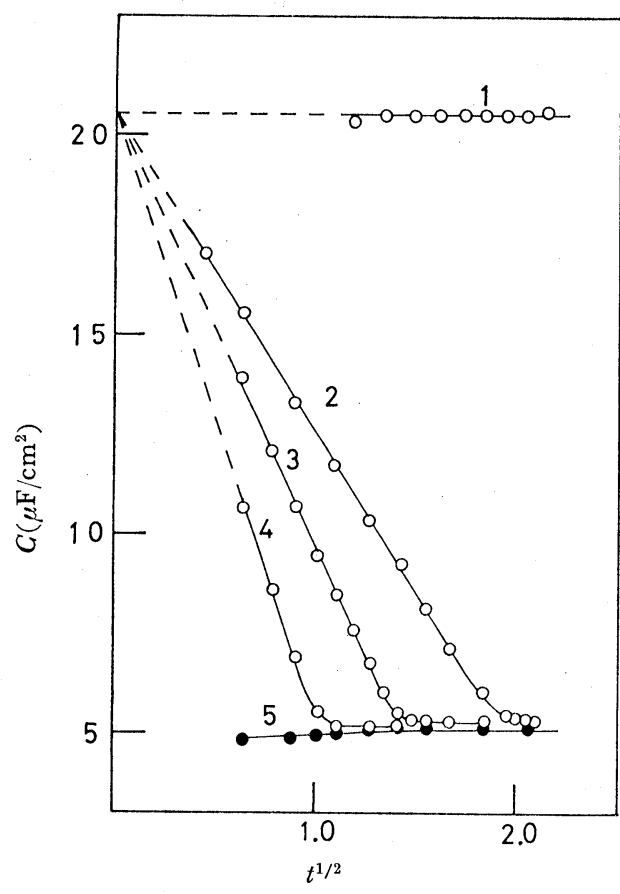

Fig. 3. Dependence of the differential capacity $C\left(\mu \mathrm{F} / \mathrm{cm}^{2}\right)$ on $t^{1 / 2}\left(\mathrm{sec}^{1 / 2}\right)$ at $E=-0.707 \mathrm{~V}$. in the solution of $(0.25 M-\mathrm{KCl}+$ concentrations of T.B.A. ; $1: 0 M ., 2: 5 \times 10^{-5}$ M., $3: 7 \times 10^{-5} M ., 4: 1 \times 10^{-4} M$., $5: 1 \times$ $10^{-3} M$.)

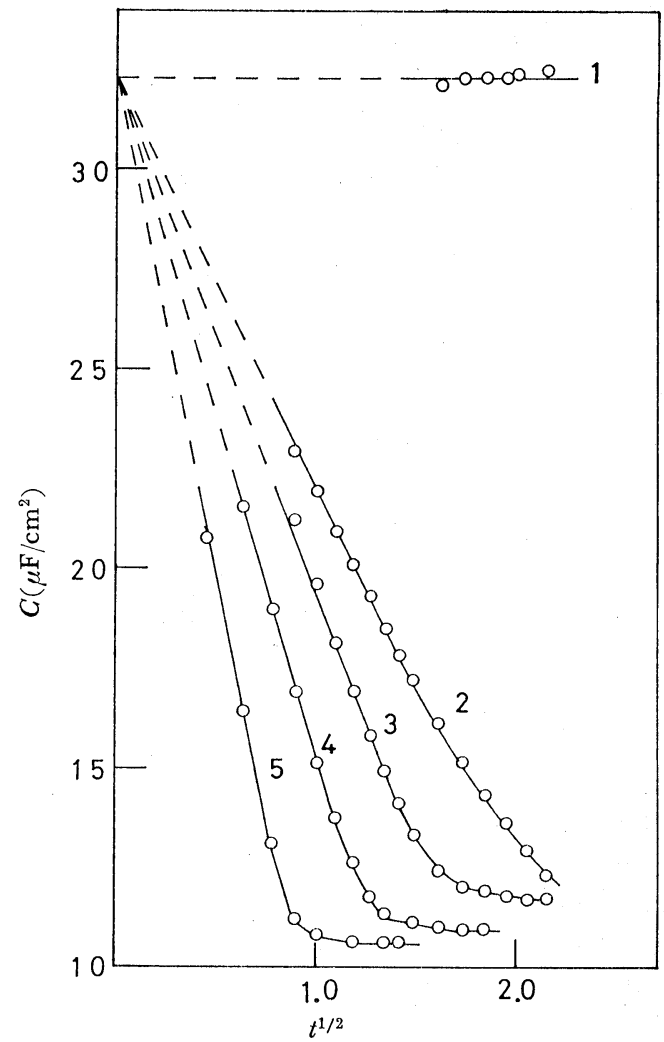

Fig. 4. Dependence of the differential capacity $C$ $\left(\mu \mathrm{F} / \mathrm{cm}^{2}\right)$ on $t^{1 / 2}\left(\mathrm{sec}^{1 / 2}\right)$ at $E=-0.243 \mathrm{~V}$. in the solutions of $\left(0.1 N-\mathrm{H}_{2} \mathrm{SO}_{4}+\right.$ concentration of P.V.A. ; $1: 0.0 \%, 2: 0.01 \%, 3$ : $0.015 \%, 4: 0.02 \%, 5: 0.03 \%$

as shown in Fig. 5 and 6 , the plots of differential capacity $C$ is straight line from $t=0$ to a certain value $t_{h}$ at which a hump appears. The shape and magnitude of the hump depends on the electrode potential, concentration of the adsorbent and temperature in a complicated manner. The appearance of the hump may be due to the change of adsorbed states of tribenzylamine on the electrode surface.

Fig. 5 and 6 shows that the surface excess of tribenzylamine from $t=0$ to $t=t_{h}$ is controlled only by the diffusion.

The dependence of $C-t^{1 / 2}$ curves on the electrode potes tial are given in Fig. 7, Fig. 8, and Fig. 9 for T.B.A., P.V.A., and tribenzylamine, res sectively. Let the intersection of the extension of straight part of $C-t^{1 / 2}$ curves and a line as to $C^{\prime}(\theta=1)$ be $t_{\theta=1}^{1 / 2}{ }^{*}$, then these figures indicate that the value of $t_{\theta=1}^{1 / 2}$ at various potential give the same value at a given composition of the electrolyte.

The relative coverage calculated from the data in Fig. 7-9 using eqn. (3) is plotted against $t^{1 / 2}$ in Fig. 10. The plots give a straight line, and change negligibly with the electrode potential. In Fig. 10 the intersection of the straight line and the horizontal

* In practice, when $\theta$ approaches to unity, $G-t^{1 / 2}$ curves deviates slightly from eqn. (2), and the true value of $t^{1 / 2}$ corresponding to $\theta=1$ is larger than the value of $t_{\theta=1}^{1 / 2}$ 


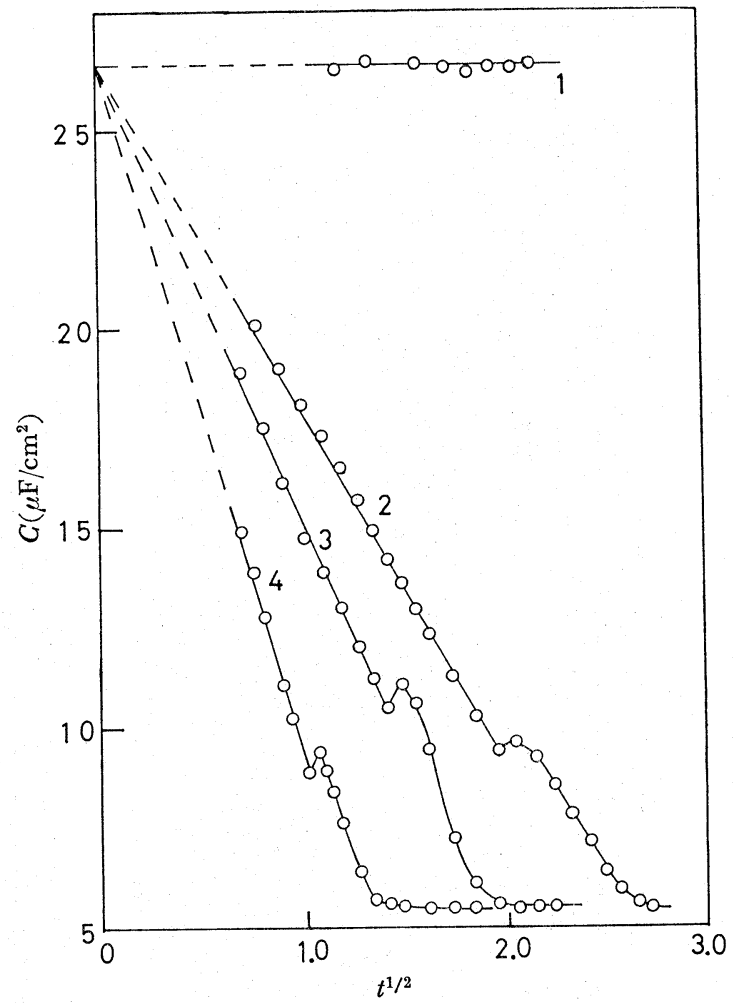

Fig. 5. Dependence of the differential capacity $C$ $\left(\mu \mathrm{F} / \mathrm{cm}^{2}\right)$ on $t^{1 / 2}\left(\sec ^{1 / 2}\right)$ at $E=-0.422 \mathrm{~V}$. in the solutions of $\left(0.2 \mathrm{~N}-\mathrm{H}_{2} \mathrm{SO}_{4}+\right.$ concentrations of tribenzylamine ; $1: 0 M ., 2: 5 \times$ $10^{-5} M ., 3: 7 \times 10^{-5} M ., 4: 1 \times 10^{-4} M$ )

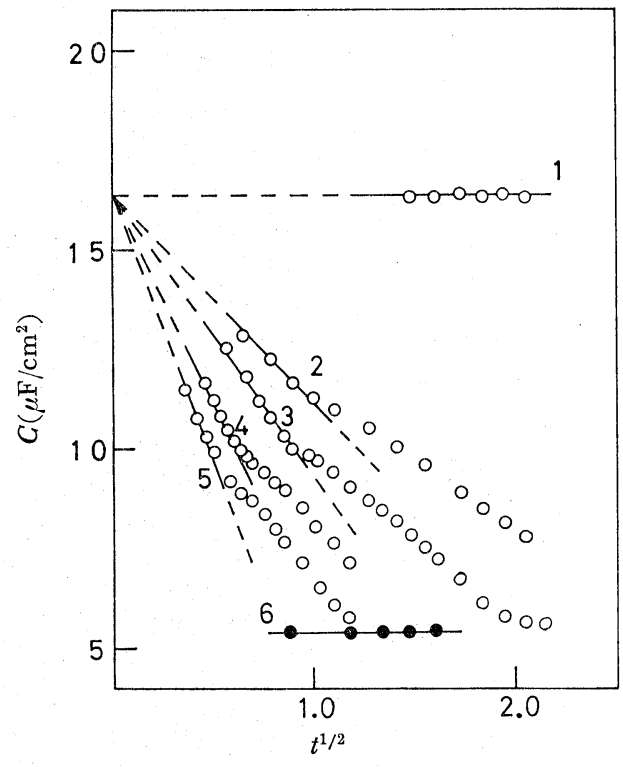

Fig. 6. Dependence of the differential capacity $C\left(\mu \mathrm{F} / \mathrm{cm}^{2}\right)$ on $t^{1 / 2}\left(\mathrm{sec}^{1 / 2}\right)$ at $E=-0.909 \mathrm{~V}$. in the solutions of $(0.2 \mathrm{~N}-\mathrm{HCl}+$ concentrations of tribenzylamine ; $1: 0.0 \mathrm{M}$, $2: 5 \times 10^{-5} M ., \quad 3: 7 \times 10^{-5} M ., 4: 1 \times 10^{-4}$ M., $5: 1.4 \times 10^{-4} M ., 6: 7 \times 10^{-4} M$ )

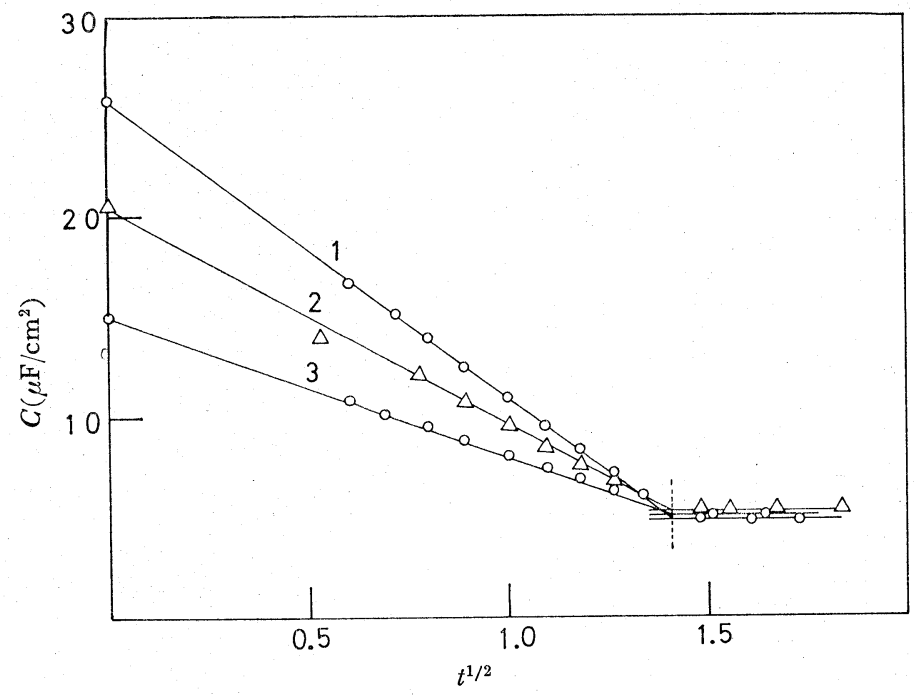

Fig. 7. Dependence of the difference capacity $G\left(\mu \mathrm{F} / \mathrm{cm}^{2}\right)$ on $t^{1 / 2}\left(\mathrm{sec}^{1 / 2}\right)$ in the solution of $\left(0.25 M-\mathrm{KCl}+7 \times 10^{-5} M\right.$ - T.B.A. $)$ at the electrode potential ; $1: E=-0.570 \mathrm{~V} ., 2: E=-0.707 \mathrm{~V} ., 3: E=-0.976 \mathrm{~V}$. 


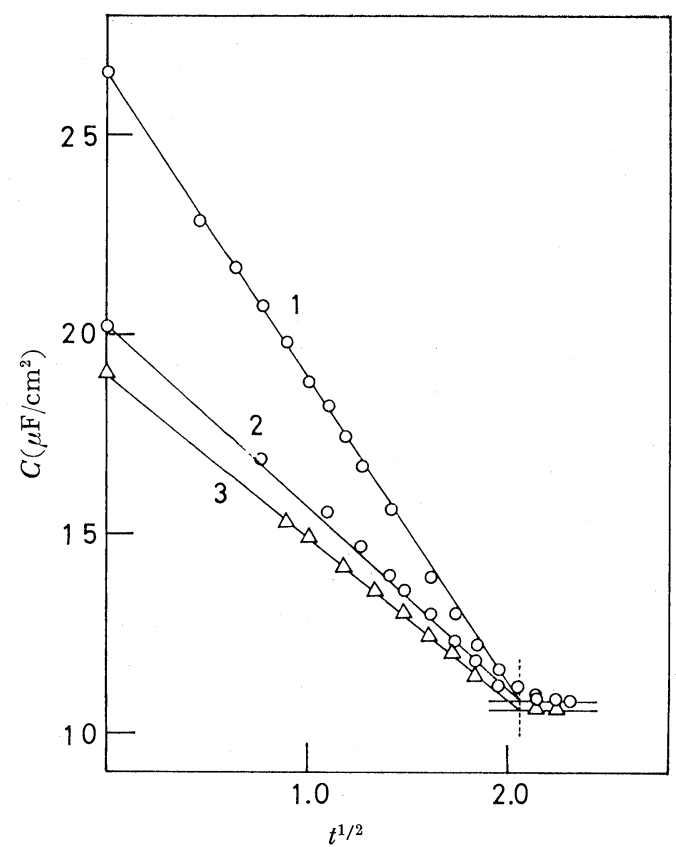

Fig. 8. Dependence of the differential capacity $C$ $\left(\mu \mathrm{F} / \mathrm{cm}^{2}\right)$ on $t^{1 / 2}\left(\mathrm{sec}^{1 / 2}\right)$ in the solution of $\left(0.2 \mathrm{~N}-\mathrm{H}_{2} \mathrm{SO}_{4}+0.015 \%\right.$ P.V.A. $)$ at the electrode potential ; $1: E=-0.422 \mathrm{~V} ., 2: E=-$ $0.569 \mathrm{~V} ., 3: E=-0.707 \mathrm{~V}$. (at the temperature $10^{\circ} \mathrm{C}$ )

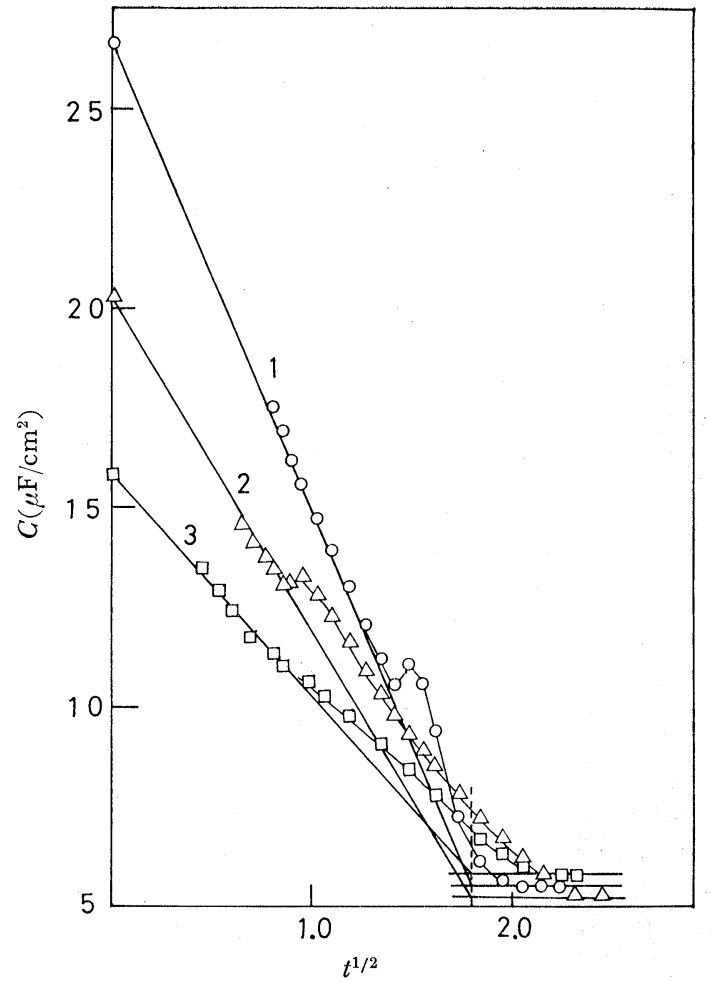

Fig. 9. Dependence of the differential capacity $C$ $\left(\mu \mathrm{F} / \mathrm{cm}^{2}\right)$ on $t^{1 / 2}\left(\mathrm{sec}^{1 / 2}\right)$ in the solution of $\left(0.2 \mathrm{~N}-\mathrm{H}_{2} \mathrm{SO}_{4}+7 \times 10^{-5} M\right.$-tribenzylamine) at the electrode potential ; $1: E=-0.422 \mathrm{~V}$, $2: E=-0.569 \mathrm{~V} ., 3: E=-0.973 \mathrm{~V}$.

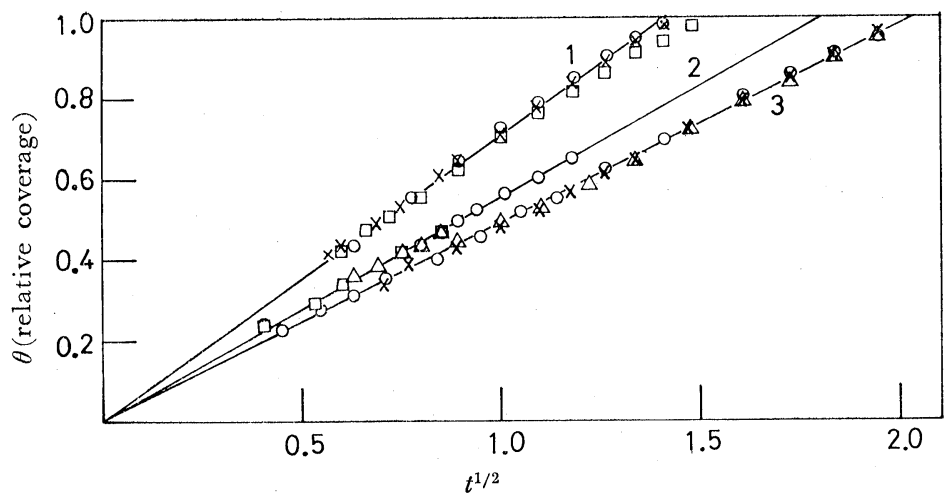

Fig. 10. Dependence of the relative coverage $\theta$ on $t^{1 / 2}\left(\sec ^{1 / 2}\right)$

1. $7 \times 10^{-5} M$-T.B.A. $+0.25 M-\mathrm{KGl}$

$\times: E=-0.570 \mathrm{~V} ., \bigcirc: E=-0.707 \mathrm{~V} ., \square: E=-0.976 \mathrm{~V} .25^{\circ} \mathrm{C}$

2. $7 \times 10^{-5} M$ tribenzylamine $+0.2 N-\mathrm{H}_{2} \mathrm{SO}_{4}$

$\bigcirc: E=-0.422 \mathrm{~V} ., \triangle: E=-0.569 \mathrm{~V} ., \square: E=-0.973 \mathrm{~V} .25^{\circ} \mathrm{C}$

3. $0.015 \%-$ P.V.A. $+0.2 \mathrm{~N}-\mathrm{H}_{2} \mathrm{SO}_{4}$

$\bigcirc: E=-0.422 \mathrm{~V} ., \times: E=-0.569 \mathrm{~V} ., \triangle: E=-0.707 \mathrm{~V} .10^{\circ} \mathrm{C}$ 
axis for $\theta=1$ is $t_{\theta=1}^{1 / 2}$.

$t_{\theta=1}^{1 / 2}$ obtained from Fig. 10 is proportional to the inverse of concentration of surface active substances in conformity to eqn. (2) as shown in Fig. 11.

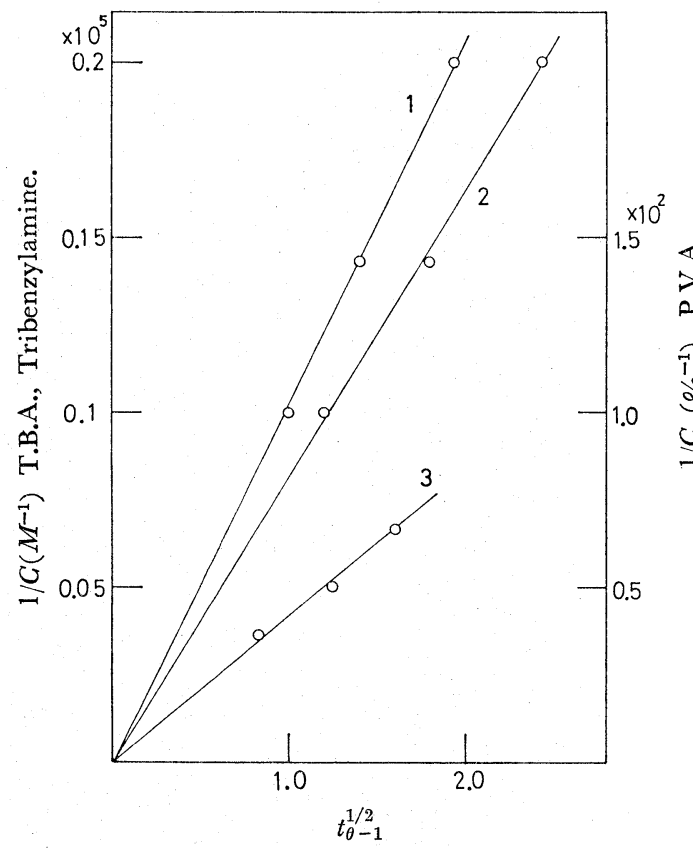

Fig. 11. Relation between $1 / c(c: \mathrm{mol} / \mathrm{l})$ and $t_{\theta=1}^{1 / 2}$ $\left(\sec ^{1 / 2}\right)$

1. T.B.A. $+0.25 M \mathrm{KCl}$

2. tribenzylamine $+0.2 \mathrm{~N}-\mathrm{H}_{2} \mathrm{SO}_{4}$

3. P.V.A. $+0.1 \mathrm{~N}-\mathrm{H}_{2} \mathrm{SO}_{4}$

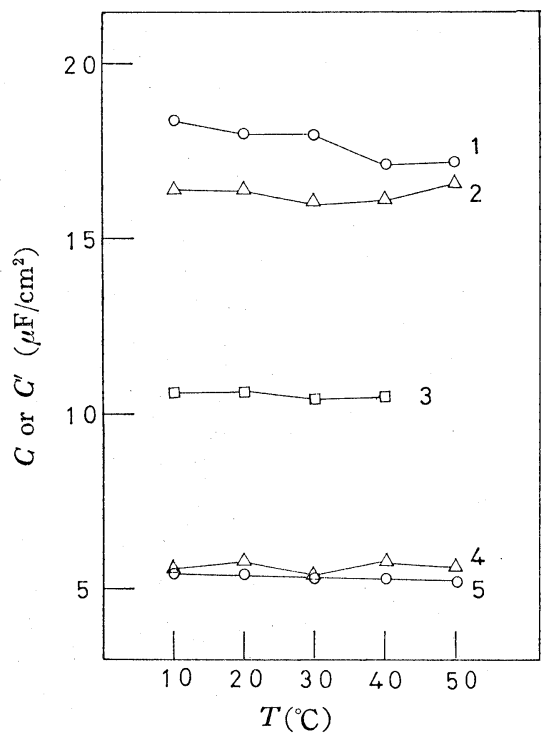

Fig. 12. Dependence of $G$ or $C^{\prime}$ (differential capacity corresponding to $\theta=1, \mu \mathrm{F} / \mathrm{cm}^{2}$ ) on temperature $T$ (in ${ }^{\circ} \mathrm{C}$ )

1. $0.2 \mathrm{~N}-\mathrm{H}_{2} \mathrm{SO}_{4}, E=-0.707 \mathrm{~V}$

2. $0.25 M-\mathrm{KCl}, E=-0.976 \mathrm{~V}$

3. $0.2 \mathrm{~N}-\mathrm{H}_{2} \mathrm{SO}_{4}+0.015 \%-$ P.V.A., $E=-0.707 \mathrm{~V}$.

4. $0.25 M-\mathrm{KCl}+5 \times 10^{-5} M-$ T.B.A., $E=-0.976 \mathrm{~V}$.

5. $0.2 N-\mathrm{H}_{2} \mathrm{SO}_{4}+8.5 \times 10^{-5} M$-tribenzylamine, $E=-0.707 \mathrm{~V}$.

According to the Arrhenius equation, the dependence of diffusion coefficient on the temperature can be expressed as

$$
D=D_{0} \cdot \exp (-Q / R T)
$$

where $D_{0}$ is frequency factor, $T$ absolute temperature, $R$ gas constant, and $Q$ the energy of activation for diffusion. Substituting eqn.(4) into eqn.(2), eqn.(2) is transformed as

$$
\theta=7.36 \times 10^{-4} \cdot c \cdot t^{1 / 2} \cdot D_{0}{ }^{1 / 2} \cdot I_{m}^{\prime}{ }^{-1} \cdot \exp (-Q / 2 R T)
$$

The differential capacity for $\theta=1$ is held constant as shown in Fig. 12, when temperature is changed from $10^{\circ} \mathrm{C}$ to $50^{\circ} \mathrm{G}$. It can be considered that $I_{m}^{\prime}$ is approximately independent of temperature within a range of $10^{\circ} \mathrm{C}-50^{\circ} \mathrm{C}$. Substituting $t^{1 / 2}=t_{\theta=1}^{1 / 2}$ and $\theta=1$ into eqn.(5), then $Q$ can be obtained at a given value of $c$, as follows.

$$
Q=4.60 \cdot R \cdot \frac{\Delta \log t_{\theta=1}^{1 / 2}}{\Delta(1 / T)}
$$

The values of $t_{\theta=1}^{1 / 2}$ for T.B.A., P.V.A., and tribenzylamine at five different temperatures were obtained by the same method as in Fig. 10. In Fig. $13 \log t_{\theta=1}^{1 / 2}$ for the three kind of adsorbates was plotted against $(1 / T)$.

Substituting the value of the inclination of the plotts into eqn.(6), the energy of activation for diffusion was evaluated as follows. 


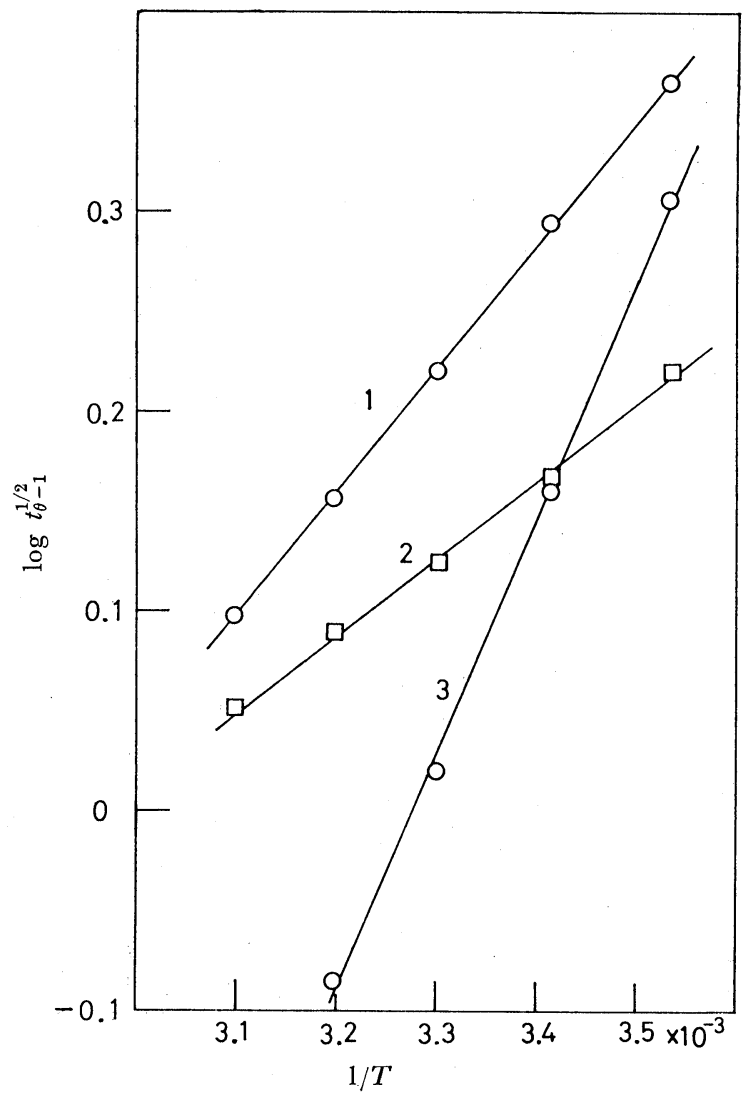

Fig. 13. Dependence of $\log \left(t_{\theta=1}^{1 / 2}\right)$ on $1 / T(T:$ absolute scale $)$

1. $0.25 M-\mathrm{KGl}+5 \times 10^{-5} M-$ T.B.A

2. $0.2 N-\mathrm{H}_{2} \mathrm{SO}_{4}+8.5 \times 10^{-5} M$-tribenzylamine

3. $0.2 \mathrm{~N}-\mathrm{H}_{2} \mathrm{SO}_{4}+0.015 \%-$ P.V.A.

T.B.A.

P.V.A.

Tribenzylamine

$$
\begin{aligned}
& Q=5.8 \mathrm{Kcal} / \mathrm{mol} \\
& Q=11.0 \mathrm{Kcal} / \mathrm{mol} \\
& Q=3.7 \mathrm{Kcal} / \mathrm{mol}
\end{aligned}
$$

\section{Acknowledgment}

The author wishes to thank Prof. Hiroaki Matsuda for his kind guidance, and Dr. Yoshio Takemori for his help.

\section{References}

1) For a review see B.B. Damaskin, O.A. Petrii, V.V. Batrakov, Adsorption of Organic Compounds on Electrodes, Plenum Press, New York (1971).

2) G.G. Barker and R.L. Faircloth, Advances in Polarography, Vol. 1, p. 313, Pergamon Press,(1960).

3) S. Vavricka, L. Nemec and J. Koryta, Coll. Czech. Chem. Comm., 31, 947, (1966).

4) J. Koryta, Coll, Czech. Chem. Comm., 18, 206, (1953).

5) A.N. Frumkin, Z. Physik, 35, 792, (1926). 
界面活性剂の吸着した水銀滴下電極の成長期間中

における微分容量の測定

$$
\begin{gathered}
\text { 綾 部 祐 } \\
\text { (東京工業試験所) }
\end{gathered}
$$

微少三角波電圧を使用した微分容量の測定方法は Barker と Faircloth そよって報告されているが，乙 の方法を界面活性剤に吸着された水銀滴下電極の成長 期間中における微分容量の時間的変化の測定に応用し た. 微分容量の $t^{1 / 2}(t$ : 時間) 飞対する変化より水銀滴 の成長期間中の吸着物質の被覆率の変化を計算し, 3 種類の界面活性剂の吸着過程が搪散律速であることを
明かにした。 とくにトリベンジルアミンの場合は滴下 の初期において拡散律速であるととがわかった。この 被覆率一時間曲線の温度依存性の值を用いて Karyta の式を基礎にして, ポリビニルアルコール，テトラブ チルアンモニウムイオンおよびトリベンヂルアミンの 拡散の活性化エネルギーを求めた。 